\title{
PENGARUH GAYA KEPEMIMPINAN DAN MOTIVASI KERJA TERHADAP KINERJA DOSEN
}

\author{
WALDA ISNA NISA \\ Fakultas Psikologi dan IImu Pendidikan (FPIP) Unira Malang \\ Jl. Mojosari 2 Kepanjen Malang \\ Email: waldha092@gmail.com
}

\begin{abstract}
Abstrak:
This study aims to determine the influence of leadership style and work motivation on the lecturers performance. This study uses a quantitative approach with survey research. Samples used a population sample that is taken from all of lectures (Fixed or not fixed) Faculty of Sains and Technology, Unira Malang as many as 24 people. Data analysis uses the prerequisite test and multiple linear regression analysis to determine the influence of leadership style and motivation of lecturers working on the lectures performance either partially or simultaneously. Based on the research we concluded that leadership style positive and significant effect on the lecturers performance. Work motivation no significant effect on the lecturers performance. Based on the f-test (simultaneously) note that the leadership style and work motivation have a significant effect on the lecturers performance. Simultaneously leadership style and work motivation influence on the lecturers performance 83.5\%, while $16.5 \%$ were influenced by variables or other factors not examined.
\end{abstract}

Keywords: Gaya Kepemimpinan, Motivasi Kerja, Kinerja Dosen

\section{PENDAHULUAN}

anajemen melibatkan proses koordinasi dan mengawasi kegiatan/karya orang lain sehingga kegiatan mereka selesai secara efisien dan efektif (Robbins \& Coulter, 2011: 8). Tidak terkecuali dalam organisasi perguruan tinggi, negeri ataupun swasta, kegiatan manajemen menjadi hal yang sangat penting untuk memastikan bahwa seluruh aktivitas organisasi dan anggota di dalamnya melaksanakan tugas, fungsi dan tanggung jawabnya masing-masing dalam rangka mencapai visi misi ataupun tujuan bersama yang telah ditetapkan.

Manajemen sendiri memiliki banyak aspek, dimana manajemen kepegawaian dan sumber daya manusia (SDM) berperan penting bagi organisasi dalam mengelola, mengatur, dan memanfaatkan pegawai sehingga dapat berfungsi secara produktif untuk tercapainya tujuan organisasi. Sumber daya manusia di organisasi perlu dikelola secara profesional agar terwujud keseimbangan antara kebutuhan pegawai dengan tuntutan dan kemampuan organisasi. Keseimbangan tersebut merupakan kunci utama organisasi atau lembaga agar dapat berkembang secara produktif dan wajar.

Menurut Robbins \& Coulter (2011) Human Resources Management (HRM) merupakan hal yang penting karena tiga alasan. Pertama, dari berbagai penelitian diketahui bahwa SDM yang berkualitas dapat menjadi sumber yang signifikan dari keuntungan kompetitif. Kedua, HRM merupakan bagian penting dari strategi organisasi. Mencapai keberhasilan kompetitif melalui SDM berarti manajer harus mengubah cara mereka berpikir tentang karyawan mereka dan bagaimana mereka 
melihat hubungan kerja. Akhirnya, cara organisasi memperlakukan orang-orang mereka telah ditemukan berdampak signifikan terhadap kinerja organisasi. Benang merah antara praktek-praktek ini tampaknya menjadi komitmen untuk melibatkan karyawan; meningkatkan pengetahuan, keterampilan, dan kemampuan organisasi para karyawan; meningkatkan motivasi mereka; mengurangi kemalasan pada pekerjaan; dan meningkatkan retensi karyawan berkualitas serta mendorong untuk meninggalkan kinerja yang rendah.

Dalam sebuah perguruan tinggi, dosen merupakan salah satu SDM yang harus selalu mendapatkan perhatian khusus dari lembaga, tidak hanya dari segi kuantitas tapi juga kualitasnya. Hal ini dikarenakan dosen memiliki peranan yang sangat penting sebagai ujung tombak pelaksana keseluruhan proses pendidikan. Dosen bertanggung jawab terhadap proses belajar mengajar, oleh karena itu dalam upaya meningkatan mutu pendidikan tinggi, dosen memegang peranan dan kedudukan kunci dalam keseluruhan proses pendidikan terutama di perguruan tinggi. Di dalam UUD No. 14 Tahun 2005 tentang Guru dan Dosen, disebutkan bahwa "Dosen adalah pendidik profesional dan ilmuwan dengan tugas utama mentransformasikan, mengembangkan, dan menyebarluaskan ilmu pengetahuan, teknologi, dan seni melalui pendidikan, penelitian, dan pengabdian kepada masyarakat".

Berdasarkan Keputusan Menteri Negara Koordinator Bidang Pengawasan Pembangunan dan Pendayagunaan Aparatur Negara Nomor: 38/KEP/MK. WASPAN/8/1999 Tentang Jabatan Fungsional Dosen dan Angka Kreditnya Pasal 3 disebutkan Tugas pokok seorang dosen adalah melaksanakan pendidikan dan pengajaran pada perguruan tinggi, penelitian serta pengabdian kepada masyarakat.

Salah satu faktor yang sangat berpengaruh bagi keberhasilan suatu perguruan tinggi dalam melaksanakan visi misinya adalah kinerja dosen. Kinerja dosen merupakan penggerak bagi keberhasilan tujuan yang hendak dicapai oleh lembaga perguruan tinggi, baik negeri ataupun swasta. Mangkunegara (2004: 67) memberikan pengertian kinerja adalah hasil kerja secara kualitas dan kuantitas yang dicapai oleh seseorang dalam melaksanakan tugasnya sesuai dengan tanggung jawab yang diberikan kepadanya.

Kinerja seorang dosen dalam menjalankan tugas dan fungsinya tidak dapat berdiri sendiri, akan tetapi berhubungan dan juga dipengaruhi oleh faktor-faktor lain, baik itu dari faktor internal ataupun eksternal dosen itu sendiri. Beberapa faktor internal yang mempengaruhi kinerja seorang dosen antara lain, motivasi kerja, kepuasaan kerja, pengalaman, kompetensi, ataupun sifat-sifat individu lainnya. Sedangkan faktor eksternal yang juga dapat mempengaruhi kinerja seorang dosen adalah, gaya kepemimpinan organisasi, lingkungan kerja, teman/rekan sejawat, kompensasi dan lain-lain. Dalam penelitian ini, peneliti hanya berfokus 
pada motivasi kerja sebagai faktor internal dan gaya kepemimpinan sebagai faktor eksternal.

Kepemimpinan (leadership) yang ditetapkan oleh seorang pemimpin dalam organisasi dapat menciptakan intergrasi yang serasi dan mendorong gairah kerja karyawan untuk mencapai sasaran yang maksimal. Tidak terkecuali dalam lembaga pendidikan tinggi sekalipun, pelaksanaan kepemimpinan diarahkan untuk cenderung menumbuhkan kepercayaan, partisipasi, loyalitas, dan internal motivasi para dosen dengan cara persuasif. Hal tersebut guna untuk meningkatkan kinerja dosen dalam menjalankan tugas Tri Darma pendidikan tinggi, mulai dari pendidikan dan pengajaran, penelitian, hingga pengabdian masyarakat. Seperti diungkap oleh Robert Tanembuan dalam buku Malayu S. P. Hasibuan (2006), Pemimpin adalah mereka yang menggunakan wewenang formal untuk mengorganisasi, mengarahkan, dan mengontro para bawahan yang bertanggung jawab, supaya semua bagian pekerjaan dikoordinasi demi mencapai tujuan organisasi.

Seorang atasan (pimpinan) diharapkan mempunyai kemampuan memimpin yang baik agar tujuan organisasi dapat tercapai. Adapun yang dimaksud dengan kemampuan memimpin adalah kemampuan untuk memotivasi, mempengaruhi, mengarahkan dan berkomunikasi dengan bawahannya. Disamping itu seorang atasan harus bersifat fleksibel, dalam arti dapat beradaptasi dengan bawahan (karyawan) dan lingkungan kerjanya. Untuk itu dibutuhkan hubungan kerja yang baik antara atasan dengan bawahan, dan antara teman sekerja sehingga mendorong melakukan kerjasama guna mencapai tujuan organisasi (Laniwidyanti: 2010).

Motivasi diambil dari bahasa Inggris yaitu kata motivation yang berasal dari bahasa latin movere yang artinya menggerakkan (Wiyono 2007: 1). Menurut Uno (2007: 3) motivasi berasal dari kata motif yaitu daya penggerak dalam diri seseorang untuk melakukan aktivitas tertentu, demi mencapai tujuan tertentu. Sedangkan Anoraga (2006: 34) mengartikan motivasi sebagai kebutuhan yang mendorong perbuatan ke arah suatu tujuan tertentu. Jadi dapat disimpulkan bahwa motivasi mempunyai arti yang sama dengan motif, yakni sebagai suatu daya pendorong untuk melakukan sesuatu.

Motivasi kerja merupakan faktor penting yang mempengaruhi kinerja dosen. Motivasi kerja sendiri adalah suatu dorongan mental yang muncul dari dalam dan luar diri dosen untuk melaksanakan tugas. Duncan dalam Uno (2007: 87) mengemukakan motivasi kerja berkaitan dengan dorongan yang muncul dari diri seseorang untuk melakukan tugas secara keseluruhan berdasarkan tanggung jawab masing-masing. Bagi seorang dosen, tugas dan tanggung jawab tersebut terlihat dalam melaksanakan Tri Dharma Perguruan Tinggi. Oleh karena itu, dosen yang mempunyai motivasi kerja yang tinggi akan menghasilkan kinerja yang tinggi pula. Hal ini diperkuat oleh penelitian yang dilakukan Setiyati (2014) yang menemukan bahwa terdapat pengaruh yang positif dan signifikan dari variabel 
motivasi kerja terhadap kinerja guru SMK Negeri di Kabupaten Gunungkidul dengan sumbangan efektif sebesar 13,03\%.

Berdasarkan uraian di atas, maka penelitian ini bertujuan untuk: 1) mengetahui pengaruh gaya kepemimpinan terhadap kinerja dosen; 2) mengetahui pengaruh motivasi kerja terhadap kinerja dosen; 3) mengetahui pengaruh secara simultan dari gaya kepemimpinan dan motivasi kerja terhadap kinerja dosen di lingkungan Fakultas Saintek Unira Malang.

\section{KAIIAN PUSTAKA}

\section{Kinerja Dosen}

Menurut Rachmawati dan Daryanto (2013: 16) Kinerja diartikan sebagai tingkat keberhasilan seseorang atau kelompok orang dalam melaksanakan tugas dan tanggung jawabnya serta kemampuan untuk mencapai tujuan dan standar yang telah ditetapkan. Kinerja juga dapat merefleksikan kesuksesan suatu organisasi, oleh karena itu dipandang penting untuk mengukur karakteristik tenaga kerjanya. Berdasarkan pendapat tersebut dapat disimpulkan bahwa kinerja adalah hasil kerja secara kualitas dan kuantitas yang dicapai seseorang dalam melakukan tugasnya sesuai dengan tanggung jawab yang diberikan kepadanya.

Undang-undang Nomor 14 Tahun 2005 tentang Guru dan Dosen, dan Peraturan Pemerintah Republik Indonesia Nomor 37 Tahun 2009 tentang Dosen, disebutkan bahwa dosen adalah pendidik profesional dan ilmuwan dengan tugas utama mentransformasikan, mengembangkan dan menyebarluaskan ilmu pengetahuan, teknologi, dan seni melalui pendidikan, penelitian dan pengabdian kepada masyarakat (Tridharma Perguruan Tinggi).

Dari uraian dan pendapat di atas dapat disimpulkan bahwa kinerja dalam penelitian ini adalah hasil kerja secara kualitas dan kuantitas yang dicapai seorang dosen dalam melaksanakan tugasnya sesuai dengan tanggung jawab yang diberikan kepadanya, khususnya dalam melaksanakan tri dharma perguruan tinggi. Kinerja merujuk kepada tingkat keberhasilan dalam melaksanakan tugas serta untuk mencapai tujuan yang telah ditetapkan. Oleh karena itu kinerja dikatakan baik, jika tujuan yang diinginkan dapat tercapai dengan baik pula.

\section{Gaya Kepempimpinan}

Institusi pendidikan tinggi saat ini menghadapi dunia yang lebih saling terkoneksi baik dalam pengetahuan, kreativitas, dan inovasi sebagai sesuatu elemen penting dalam perubahan masyarakat. Tekanan dunia global yang seperti ini, dicirikan pada dua hal percepatan dalam pertumbuhan masyarakat ilmu pengetahuan yang memiliki kecenderungan pada penguatan teknologi informasi dan komunikasi dan yang kedua adalah proses percepatan dan inovasi yang membawa pada ketidakpastian identitas, dunia kerja maupun karir. Dengan situasi ini maka institusi pendidikan tinggi di hampir semua bagian dunia berusaha mencari berbagai cara dalam memelihara keberlanjutannya (Shephard, 2008). 
Oleh karena itu kepemimpinan dalam sebuah organisasi atau lemabaga pendidikan tinggi, menghadapi tantangan yang besar dalam upaya menjamin keberlangsungan dan perkembangan lembaga dalam rangka mencapai tujuan atau mewujudkan visi misi yang telah ditetapkan.

Kepemimpinan adalah kemampuan seseorang untuk menguasai atau mempengaruhi orang lain atau masyarakat yang berbeda-beda menuju pencapaian tujuan (Arep, 2002: 93). Sedangkan menurut Handoko (2003: 294) kepemimpinan adalah kemampuan yang dipunyai seseorang untuk mempengaruhi orang lain agar bekerja mencapai tujuan dan sasaran. Dari pendapat-pendapat tersebut maka dapat disimpulkan bahwa kepemimpinan merupakan usaha yang dilakukan oleh seseorang dengan segenap kemampuan yang dimiliki untuk mempengaruhi, mendorong, mengerahkan dan menggerakkan orang-orang yang dipimpin supaya mereka mau bekerja dengan penuh semangat dan kepercayaan dalam mencapai tujuannya.

Dharma (1992: 114) mengatakan bahwa gaya kepemimpinan seseorang adalah pola perilaku yang diperlihatkan seseorang pada waktu berupaya mempengaruhi aktifitas orang lain seperti yang dipersepsikan orang tersebut. Menurut De Coster dan Fertakis (1968), gaya kepemimpinan dapat dibagi dalam dua dimensi yaitu pertama, struktur inisiatif (initiating structure) yang menunjukkan perilaku pemimpin yang dihubungkan dengan kinerja pekerjaan. Yang kedua, gaya kepemimpinan pertimbangan (consideration) yang menunjukkan hubungan dekat, saling mempercayai dan saling memperhatikan antara pimpinan dan bawahan.

Dari beberapa uraian di atas dapat disimpulkan bahwa kepemimpinan adalah kemampuan yang dimiliki oleh tiap pemimpin untuk mempengaruhi dan menggerakkan bawahannya sedemikian rupa agar bawahannya tersebut dapat bekerja lebih semangat, bersedia bekerja sama dan mampu bekerja dengan disiplin tinggi terhadap tugas yang telah diberikan.

\section{Motivasi Kerja}

Motivasi adalah sesuatu yang memulai gerakan, sesuatu yang membuat orang bertindak atau berperilaku dalam cara-cara tertentu. Memotivasi orang adalah menunjukkan arah tertentu kepada mereka dan mengambil langkahlangkah yang perlu untuk memastikan bahwa mereka sampai kesuatu tujuan. Motivasi lahir dari berbagai konsep teory diantaranya adalah need theory, equity theory, dan expectancy theory. Analisis mengenai motivasi harus memusatkan perhatian pada faktor-faktor yang mendorong dan mengarahkan kegiatan seseorang. Seorang ahli menekankan pada aspek motivasi yang mengarah pada tujuan.

Reksohadiprodjo (1990) mendefinisikan motivasi sebagai keadaan dalam pribadi seseorang yang mendorong keinginan individu untuk melakukan kegiatankegiatan tertentu untuk mencapai suatu tujuan. Setiap kegiatan yang dilakukan 
oleh seseorang didorong oleh suatu kekuasaan dari dalam diri orang tersebut. Kekuatan pendorong inilah yang disebut sebagai motivasi. Moekijat (1992) mengemukakan bahwa motivasi merupakan proses atau faktor yang mendorong orang untuk bertindak atau berperilaku dengan cara tertentu. Proses motivasi mencakup tiga hal, yaitu: pengenalan dan penilaian kebutuhan yang belum terpuaskan, penentuan tujuan yang akan menentukan kepuasan, serta penentuan tindakan yang diperlukan untuk memuaskan kebutuhan.

Bagi seorang dosen, motivasi kerja menjadi penting untuk menjamin bahwa profesinya sebagai seorang pendidik dapat memberikan prestasi kerja yang maksimal dalam menjalankan tugasnya. Menurut Trisnaningsih (2011) motivasi penting karena dengan motivasi diharapkan setiap individu bekerja keras dan antusias untuk mencapai hasil kerja yang tinggi. Motivasi kerja secara umum dapat diidentifikasikan sebagai serangkaian kekuatan penggerak yang muncul dari dalam dan diluar diri masing-masing individu. Kedua kekuatan itu menimbulkan minat kerja dan berhubungan dengan tingkah laku dan menentukan arah, intensitas dan durasi dari tingkah laku atau kebiasaan individual.

Tabel 1 di bawah ini menunjukkan masing-masing variabel dan indikator yang digunakan dalam penellitian:

Tabel 1.1 Variabel dan Indikator Penelitian

\begin{tabular}{|c|c|c|c|}
\hline Variabel & Indikator & Item & Pengukuran \\
\hline $\begin{array}{l}\text { Gaya } \\
\text { Kepemimpinan } \\
\left(\mathrm{X}_{1}\right)\end{array}$ & $\begin{array}{l}\text { Contingent Reward } \\
\text { Manajemen Eksepsi } \\
\text { Aktif } \\
\text { Manajemen Eksepsi } \\
\text { Pasif }\end{array}$ & $\begin{array}{l}\text { Pedoman kerja } \\
>\text { Imbalan/ reward } \\
>\text { Perbaikan } \\
>\text { Controlling } \\
>\text { Warning and } \\
\quad \text { punishment }\end{array}$ & Skala Likert \\
\hline $\begin{array}{l}\text { Motivasi Kerja } \\
\left(\mathrm{X}_{2}\right)\end{array}$ & $\begin{array}{l}\text { Minat dan } \\
\text { kemampuan } \\
\text { Semangat atau } \\
\text { dorongan kerja }\end{array}$ & $\begin{array}{l}\text { Pekerjaan yang } \\
\text { sesuai dengan } \\
\text { bidangnya } \\
\text { Gaji, bonus Asuransi } \\
\text { kesehatan } \\
\text { Penghargaan } \\
\end{array}$ & Skala Likert \\
\hline $\begin{array}{l}\text { Kinerja Dosen } \\
(\mathrm{Y})\end{array}$ & $\begin{array}{l}\text { Pendidikan } \\
\text { Pengajaran } \\
\text { Penelitian }\end{array}$ & $\begin{array}{l}\text { Hubungan dengan } \\
\text { mahasiswa } \\
>\text { Penguasaan materi } \\
>\text { Kegiatan penelitian }\end{array}$ & Skala Likert \\
\hline
\end{tabular}

Dari uraian di atas maka kerangka pemikiran dalam penelitian ini dapat dilihat pada gambar diagram berikut: 


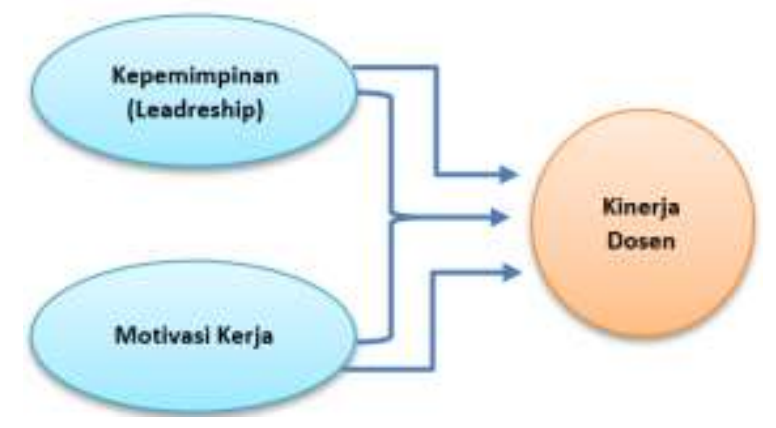

\section{Gambar 1 Kerangka berpikir penelitian}

Berdasarkan kerangka pemikiran dan rumusan masalah yag diajukan, maka hipotesis dalam penelitian ini adalah: (1) Gaya kepemimpinan berpengaruh positif dan signifikan terhadap kinerja dosen; (2) Motivasi kerja berpengaruh positif dan signifikan terhadap kinerja dosen; (3) Gaya kepemimpinan dan Motivasi kerja secara bersama-sama berpengaruh positif dan signifikan terhadap kinerja dosen.

\section{METODE PENELITIAN}

Penelitian ini menggunakan metode kuantitatif dengan jenis penelitian survey. Populasi dalam penelitian ini adalah seluruh dosen di lingkungan kerja Fakultas Sain dan Teknologi (F. Saintek) - Unira Malang. Pengambilan sampel dalam penelitian ini dilakukan dengan menggunakan teknik sampling jenuh, yaitu teknik penentuan sampel bila semua anggota populasi digunakan sebagai sampel. Hal ini sering dilakukan bila jumlah populasi relatif kecil (Sugiyono, 2011:85). Dengan demikian, jumlah sampel yang digunakan untuk penelitian ini merupakan keseluruhan dosen dalam lingkungan kerja F. Saintek, Unira Malang yang berjumlah 24 orang.

Variabel penelitian yang digunakan dalam penelitian ini yaitu kinerja dosen, gaya kepemimpinan, dan motivasi kerja. Metode pengumpulan data menggunakan angket/kuisioner. Adapun angket yang disusun adalah terdiri dari jenis angket terbuka dan tertutup. Angket terbuka digunakan untuk meminta koresponden mengisi biodata, mulai dari nama, umur hingga masa kerja. Sedangkan angket tertutup yaitu angket yang sudah disediakan alternatif jawabanya sehingga akan memudahkan koresponden untuk menjawab, pada bagian ini angket tertutup digunakan untuk mengukur variabel-variabel yang akan diteliti.

Metode pengolahan dan analisis data terbagi menjadi dua yaitu uji prasyarat dan uji regresi linear berganda dengan menggunakan bantuan program SPSS for windows release 20,0. Uji prasyarat yang dilakukan meliputi, uji normalitas dengan menggunakan rumus Kolmogrov-Smirnov, uji linearitas data melalui test of linierity dengan taraf signifikansi 0,05 dan uji multikolonieritas dengan melihat nilai VIF kurang 10. Sedangkan uji hipotesis menggunakan analisis regresi linear berganda yaitu menggunakan uji simultan (uji F) dengan membandingkan probabilitas 
dengan taraf signifikansi (5\%), uji parsial (uji t) dengan membandingkan probabilitas dengan taraf signifikansi $(5 \%)$, dan koefisien determinasi simultan $\left(\mathrm{R}^{2}\right)$ untuk melihat besarnya pengaruh gaya kepemimpinan dan motivasi kerja terhadap kinerja dosen, khususnya di lingkungan kerja F. SAINTEK, Unira Malang.

\section{HASIL PENELITIAN DAN PEMBAHASAN}

Sebelum dilakukan pengujian hipotesis, maka terlebih dahulu dilakukan uji asumsi klasik (uji prasyarat). Alat uji asumsi klasik yang digunakan adalah uji normalitas, linieritas dan multikolinieritas. Apabila uji asumsi klasik telah terpenuhi maka alat analisis regresi dapat digunakan. Sedangkan uji hipotesis digunakan untuk menguji apakah hipotesis-hipotesis penelitian yang telah dirumuskan, diterima atau ditolak. Uji normalitas dilakukan dengan menggunakan one sample Kolmogorov - Smirnov dengan taraf signifikansi 0,05. Pengujian linieritas dilakukan dengan melihat nilai $P_{\text {hitung }}$ pada baris deviation from linierity, kemudian dibandingkan dengan taraf signifikansi sebesar 0,05. Sedangkan uji multikolinieritas bertujuan untuk menguji apakah ada hubungan linier atau tidak antar variabel bebas dalam model regresi. Jika terjadi korelasi maka terdapat persoalan multikolinieritas, karena seharusnya tidak boleh terjadi korelasi antar variabel bebas. Untuk mendeteksi gejala multikolinieritas dilakukan dengan melihat nilai Variance Inflation Factor (VIF).

\section{Uji Normalitas}

Uji normalitas dalam penelitian ini dilakukan dengan menggunakan rumus Kolmogorov-Smirnov dengan bantuan program SPSS versi 20.0 for Windows. Kriteria yang digunakan adalah data dikatakan berdistribusi normal jika nilai probabilitas (asymp. Sig. (2-tailed)) pada output Kolmogorov-Smirnov > taraf signifikansi $(\alpha)$ yang ditentukan yaitu $5 \%(0,05)$. Berdasarkan hasil uji normalitas yang dilakukan menunjukkan nilai Asymp. Sig. 0,160 lebih besar dari nilai signifikansi $5 \%$. Dengan demikian data penelitian yang didapat memiliki distribusi normal. Lebih jelasnya, hasil pengujian normalitas ini dapat dilihat pada tabel 2 berikut:

Tabel 2 Variabel dan Indikator Penelitian

One-Sample Kolmogorov-Smirnov Test

\begin{tabular}{|ll|r|}
\hline & & \multicolumn{2}{|c|}{$\begin{array}{c}\text { Unstandardized } \\
\text { Residual }\end{array}$} \\
\hline N & Mean & 24 \\
Normal Parametersa,b & $0 \mathrm{E}-7$ \\
& Std. Deviation &, 99250138 \\
Most Extreme & Absolute &, 229 \\
Differences & Positive &, 111 \\
Kolmogorov-Smirnov Z & Negative &,- 229 \\
Asymp. Sig. (2-tailed) & & 1,123 \\
\hline
\end{tabular}


a. Test distribution is Normal.

b. Calculated from data.

\section{Uji Linieritas}

Uji linieritas data bertujuan untuk mengetahui pola hubungan antara masingmasing variabel bebas dengan variabel terikat berbentuk linier atau tidak. Uji linieritas dalam penelitian ini dilakukan dengan menggunakan test of linierity dengan taraf signifikansi 0,05. Hasil uji linieritas menunjukkan bahwa: 1) hubungan antara gaya kepemimpinan dan kinerja dosen adalah hubungan linear, hal ini terlihat dari nilai deviation from linierity $0,798>0,05 ; 2)$ hubungan antara motivasi kerja dan kinerja dosen adalah hubungan linear, hal ini terlihat dari nilai deviation from linierity 0,457 > 0,05. Lebih jelasnya, hasil pengujian linieritas ini dapat dilihat pada tabel 3 berikut:

Tabel 3 Statistik Hasil Uji Linieritas Antar Variabel Penelitian

\begin{tabular}{cccc}
\hline \multirow{2}{*}{ Variabel } & \multicolumn{3}{c}{ Anova Table } \\
\cline { 2 - 4 } & Deviation From Linierity & Kondisi & Keterangan \\
\hline Kepemimpinan * Kinerja_Dosen & 0,798 & $>0,05$ & Linier \\
Motivasi_Kerja * Kinerja_Dosen & 0,457 & $>0,05$ & Linier \\
\hline
\end{tabular}

\section{Uji Multikolinieritas}

Uji multikolinieritas merupakan salah satu uji asumsi klasik untuk regresi ganda. Asumsi multikolinieritas menyatakan bahwa variabel bebas harus terbebas dari gejala multikolinieritas, yang artinya bahwa antara variabel-variabel bebas yang diteliti tidak boleh berkorelaasi. Uji multikolinieritas dalam penelitian ini ditentukan dengan metode VIF (Variance Inflation Factor) dengan bantuan program SPSS versi 20.0 for Windows. Lebih jelasnya, hasil pengujian multikolinieritas ini dapat dilihat pada tabel 4 berikut:

Tabel 4 Statistik Hasil Uji Regresi

Coefficientsa

\begin{tabular}{|c|c|c|c|c|c|c|c|c|}
\hline & \multirow{2}{*}{ Model } & \multicolumn{2}{|c|}{$\begin{array}{l}\text { Unstandardized } \\
\text { Coefficients }\end{array}$} & \multirow{2}{*}{$\begin{array}{c}\begin{array}{c}\text { Standardized } \\
\text { Coefficients }\end{array} \\
\text { Beta }\end{array}$} & \multirow{2}{*}{$\mathrm{t}$} & \multirow{2}{*}{ Sig. } & \multicolumn{2}{|c|}{ Collinearity Statistics } \\
\hline & & B & $\begin{array}{l}\text { Std. } \\
\text { Error }\end{array}$ & & & & Tolerance & VIF \\
\hline \multirow{3}{*}{1} & (Constant) & 15,346 & 2,536 & & $\begin{array}{l}6,0 \\
52\end{array}$ & ,000 & & \\
\hline & GK & 1,047 & ,225 & ,767 & $\begin{array}{l}4,6 \\
45\end{array}$ & ,000 & ,264 & 3,791 \\
\hline & $\mathrm{MK}$ & 119 & 113 & 175 & $\begin{array}{l}1,0 \\
58\end{array}$ & ,302 & ,264 & 3,791 \\
\hline
\end{tabular}

a. Dependent Variable: KD

Berdasarkan hasil pengujian multikolinieritas dapat dilihat bahwa nilai VIF setiap variabel bebas kurang dari 10 (VIF < 10), sehingga dapat disimpulkan bahwa 
tidak terjadi gejala multikolinieritas antar variabel bebas penelitian. Data selengkapnya untuk hasil uji multikolinieritas antar variabel bebas $\left(X_{1}\right.$ dan $\left.X_{2}\right)$.

\section{Analisis Regresi}

Analisis regresi berganda dilakukan dengan menggunakan bantuan program SPSS for Windows Release 20.0, pada Tabel 1.3 di atas dapat dilihat bahwa konstanta sebesar 15,346, koefisien regresi untuk variabel gaya kepemimpinana sebesar 0,767 dan koefisien untuk variabel motivasi kerja sebesar 0,175. Sehingga model persamaan regresi yang diperoleh dapat dinyatakan sebagai berikut:

$Y=15,346+0,767 \cdot X_{1}+0,175 \cdot X_{2}$

\section{Uji parsial (t-test)}

Hasil uji parsial (t-test) untuk mengetahui pengaruh dari variabel gaya kepemimpinan $\left(\mathrm{X}_{1}\right)$ dan motivasi kerja $\left(\mathrm{X}_{2}\right)$ terhadap Kinerja dosen $(\mathrm{Y})$ dapat dilihat berdasarak nilai sig. yang ditunjukkan pada Tabel 1.3.

\section{Pengaruh Gaya kepemimpinan $\left(\mathrm{X}_{1}\right)$ terhadap Kinerja dosen $(\mathrm{Y})$}

Pada variabel gaya kepemimpinan dengan taraf signifikansi $95 \%(\alpha=0,05)$ diperoleh nilai signifikansi $t$ sebesar 0,000. Dari tabel 1.3 di atas diketahui bahwa nilai signifikansi $t=0,000<\alpha=0,05$ sehingga dapat dikatakan bahwa hipotesis nol $\left(\mathrm{H}_{0}\right)$ ditolak yang artinya gaya kepemimpinan berpengaruh positif dan signifikan terhadap kinerja dosen. Koefisien regresi variabel gaya kepemimpinan tersebut sebesar 0,767 dan signifikan pada taraf signifikansi $95 \%(\alpha=0,05)$. Semakin baik gaya kepemimpinan yang diterima oleh dosen, maka semakin tinggi pula kinerja yang akan ditunjukkan dosen tersebut dalam menjalankan tugas dan kewajibannya, demikian juga sebaliknya.

Hasil pengujian hipotesis tersebut sesuai dengan penelitian yang dilakukan oleh Dewi (2012) yang menyatakan bahwa kepemimpinan transformasional memiliki peran penting terhadap pencapaian kinerja, dengan karakteristik menunjukkan tingkah laku karismatik, memberikan inspirasi dan motivasi, menstimulasi pengembangan intelektual, dan mempertimbangkan kepentingan masing-masing individu dari bawahan. Penelitian lain juga dilakukan oleh Milwati (2013) menyimpulkan bahwa kinerja dosen menjadi variabel endogen yang memiliki hubungan struktural dengan kepemimpinan transformasional.

\section{Pengaruh Motivasi kerja $\left(\mathrm{X}_{2}\right)$ terhadap Kinerja dosen $(\mathrm{Y})$}

Pada variabel gaya kepemimpinan dengan tingkat signifikansi $95 \%(\alpha=0,05)$ diperoleh nilai signifikansi $t$ sebesar 0,302. Jika nilai signifikansi t dibandingkan dengan $\alpha$ maka diketahui nilai signifikansi $t=0,302>\alpha=0,05$ sehingga dapat dikatakan hipotesis nol $\left(\mathrm{H}_{0}\right)$ gagal ditolak. Artinya, Motivasi kerja tidak berpengaruh signifikan terhadap Kinerja dosen. Dari analisis regresi yang dilakukan juga diketahui bahwa koefisien regresi dari variabel motivasi kerja $\left(\mathrm{X}_{2}\right)$ hanya sebesar 
0,175 , sehingga pada taraf signifikansi 0,05 variabel bebas ini tidak berpengaruh signifikan terhadap kinerja dosen. Hal ini bisa saja terjadi dikarenakan adanya faktor-faktor lain yang mempengaruhi kinerja dosen, selain faktor kepemimpinan, diketahui bahwa profil sebagian besar dosen yang diteliti berusia relatif muda dan masih minimal dalam pengalaman atau profesinya sebagai seorang dosen.

\section{Uji Simultan (F-test)}

Uji signifikansi untuk mengetahui apakah model persamaan regresi dapat digunakan untuk menarik kesimpulan atau apakah persamaan regresi tersebut signifikan atau tidak, dapat diketahui dengan menggunakan analisis varian (uji F). Uji signifikansi persamaan regresi tersebut dapat dilihat pada tabel 5 berikut.

Tabel 5 Uji signikansi (Uji F)

ANOVAa

\begin{tabular}{|ll|r|r|r|r|r|}
\hline \multicolumn{1}{|l|}{ Model } & Sum of Squares & df & $\begin{array}{c}\text { Mean } \\
\text { Square }\end{array}$ & F & \multicolumn{1}{c|}{ Sig. } \\
\hline \multirow{2}{*}{1} & Regression & 127,302 & 2 & 63,651 & 58,998 &, $000^{\mathrm{b}}$ \\
& Residual & 22,656 & 21 & 1,079 & & \\
& Total & 149,958 & 23 & & & \\
\hline
\end{tabular}

a. Dependent Variable: KD

b. Predictors: (Constant), MK, GK

Dari Tabel 5 di atas diketahui bahwa nilai sig. $=0,000$ lebih kecil dari signifikansi $(0,05)$ atau $0,000<0,05$, sehingga $\mathrm{H}_{0}$ ditolak, atau dapat disimpulkan bahwa, persamaan regresi tersebut signifikan. Dengan demikian, persamaan regresi dapat digunakan untuk menjelaskan dan mengambil kesimpulan bahwa gaya kepemimpinan $\left(X_{1}\right)$ dan motivasi kerja $\left(X_{2}\right)$ berpengaruh signifikan terhadap kinerja dosen (Y).

Besarnya pengaruh gaya kepemimpinan dan motivasi kerja terhadap kinerja dosen dapat diketahui dari harga koefisien determinasi simultan $\left(R^{2}\right)$ yang ditunjukkan pada tabel 6 berikut ini.

Tabel 6 Hasil Uji Koefisien Determinasi

Model Summary

\begin{tabular}{|l|r|r|r|r|}
\hline Model & \multicolumn{1}{|c|}{ R } & \multicolumn{1}{|c|}{ R Square } & Adjusted R Square & Std. Error of the Estimate \\
\hline 1 &, $921^{\mathrm{a}}$ &, 849 &, 835 & 1,039 \\
\hline
\end{tabular}

a. Predictors: (Constant), MK, GK

Berdasarkan pada Tabel 1.5 di atas, diketahui bahwa nilai $\mathrm{R}$ square $\left(\mathrm{R}^{2}\right)$ adalah sebesar 0,835 yang berarti bahwa, gaya kepemimpinan dan motivasi kerja secara bersama-sama berpengaruh $83,5 \%$ terhadap kinerja dosen, sedangkan $16,5 \%$ sisanya dipengaruhi oleh variabel atau faktor lain yang tidak diteliti. 


\section{KESIMPULAN DAN SARAN}

Berdasarkan hasil penelitian dan pembahasan yang telah dilakukan di atas, maka dapat ditarik beberapa kesimpulan sebagai berikut:

1. Gaya kepemimpinan berpengaruh positif dan signifikan terhadap kinerja dosen. Artinya semakin baik gaya kepemimpinan dalam lembaga, maka semakin tinggi pula kinerja yang akan ditunjukkan dosen tersebut dalam menjalankan tugas dan kewajibannya, dan demikian juga sebaliknya.

2. Motivasi kerja tidak berpengaruh signifikan terhadap kinerja dosen. Hasil ini berdasarkan nilai sig. 0,302 >0,05, sehingga $\mathrm{H}_{0}$ gagal ditolak.

3. Berdasarkan uji f (simultan) diketahui bahwa Gaya kepemimpinan dan motivasi kerja berpengaruh signifikan terhadap kinerja dosen.

Berdasarkan beberapa kesimpulan tersebut, maka penulis dapat memberikan beberapa saran sebagai berikut:

1. Para pimpinan perguruan tinggi harus menjadi sosok pemimpin yang baik yang mampu menjalin hubungan emosional dan iklim kerja yang kondusif dengan para dosen khususnya di lingkunga kerja F. SAINTEK, sehingga mendapatkan respon dan kesan positif yang mampu meningkatkan kinerja dosen dalam menjalankan tugas dan kewajibannya.

2. Untuk meningkatkan motivasi kerja para dosen khususnya di lingkunga kerja $F$. SAINTEK agar mencapai kinerja yang optimal maka perlu dilakukan, diantaranya dengan cara menjaga agar semua hak-hak dosen diberikan dengan baik dan tepat waktu, kenaikan gaji berkala sangat diharapkan oleh dosen sebagai wujud dihargainya etos kerja dan lama kerja di akademi tersebut, juga selalu menjaga hubungan yang baik sesama dosen dengan mengadakan pertemuan non formal agar hubungan selalu terjaga dengan baik.

3. Bagi penelitian kedepan atau berikutnya penting untuk mempertimbangkan perluasan variabel penelitian tidak hanya pada gaya kepemimpinan atau motivasi kerja, tetapi juga variabel-variabel lain yang juga berpengaruh terhadap kinerja dosen, baik pangaruh langsung ataupun tidak langsung. Kuesioner sebaiknya disebar pada lebih banyak lokasi atau lebih merata sehingga sampel yang diambil lebih variatif. Pada penelitian berikutnya, penilaian kinerja dosen sebaiknya dilakukan tidak melalui angket yang diisi sendiri oleh diri dosen yang bersangkutan, tetapi dapat menggunakan instrumen pengukuran yang lain misalnya seperti penilaian oleh pimpinan pada perguruan tinggi tempat dosen bekerja, sehingga data yang didapatkan tentang kinerja dapat lebih representatif. 


\section{DAFTAR PUSTAKA}

Anoraga, Pandji. 2006. Psikologi Kerja. Jakarta: PT Rineka Cipta.

Dewi, Rosmala. 2012. Kinerja Kepala Sekolah: Pengaruh Kepemimpinan Transformasional, Konflik Dan Efikasi Diri. Jurnal IImu Pendidikan, Jilid 18, Nomor 2, Desember 2012.

Dharma, Agus. 1992. Manajemen Perilaku Organisasi; Pendayagunaan Sumber Daya Manusia. Edisi Keempat. Erlangga. Jakarta

Hasibuan, H. Malayu S.P. 2002. Manajemen Sumber Daya Manusia, Edisi Revisi Kedua, BPFE-UGM, Yogyakarta.

Handoko, Hani. 2003. Managemen. Yogyakarta: BPFE.

Laniwidyanti. 2010. Pengaruh Hubungan Kerja, Pengalaman Kerja Dan Motivasi Kerja Terhadap Kinerja Karyawan Bank Central Asia (BCA) Cabang Borobudur, Malang. Jurnal Wacana Vol. 13 No.2. April 2010.

Mangkunegara, Anwar Prabu. 2004. Manajemen Sumber Daya Manusia Perusahaan. Bandung: PT Remaja Rosdakarya.

Rachmawati, Tutik dan Daryanto. 2013. Penilaian Kinerja Profesi Guru dan Angka Kreditnya. Gava Media. Malang.

Republik Indonesia. 1999. Keputusan Menteri Negara Koordinator Bidang Pengawasan Pembangunan dan Pendayagunaan Aparatur Negara Tentang Jabatan Fungsional Dosen dan Angka Kredit. Jakarta.

Republik Indonesia. 2005. Undang-Undang Nomor 14 Tahun 2005 tentang Guru dan Dosen. Jakarta.

Robbins, Stephen P. \& Coulter, Mary. 2011. Management, 11th edition. PEARSON. New Jersey.

Sugiyono. 2008. Metode Penelitian Administrasi. Bandung: Alfabeta.

Trisnaningsih. 2011. Faktor-Faktor Yang Mempengaruhi Kinerja Dosen Akuntansi. Jurnal Akuntansi \& Auditing. Volume 8/No. 1/November 2011.

Wiyono, Sutarto. 2007. Motivasi Kerja. Salatiga: Widya Sari. 